УДК $338.439 .02: 502.17$

DOI 10.15673/fie.v13i4.2192

\author{
Нікішина О.В. \\ доктор економічних наук, старший науковий співробітник \\ завідувач відділу ринкових механізмів та структур \\ E-mail: ksenkych@gmail.com \\ ORCID ID: 0000-0002-7172-3551 \\ Чеботарьова Н.Й. \\ аспірант \\ відділ ринкових механізмів та структур \\ Інститут проблем ринку та економіко-екологічних досліджень НАН України \\ Французький бульвар, 29, м. Одеса, Україна, 65044 \\ E-mail: chebotarovan@ukr.net \\ ORCID ID: 0000-0003-1790-5925
}

\title{
МЕТОДИЧНІ ПОЛОЖЕННЯ ЩОДО ОЦІНКИ НАЦІОНАЛЬНОЇ ПРОДОВОЛЬЧОЇ БЕЗПЕКИ НА ЗАСАДАХ СТАЛОГО РОЗВИТКУ*
}

У статті запропоновано методичний підхід до комплексної оцінки національної продовольчої безпеки за ланками агропродовольчого ланцюга вартості на засадах сталого розвитку. Розроблено методичні положення до оцінки продовольчої безпеки в аграрному секторі (сировинна ланка ланцюга вартості) та систему загальних і специфічних індикаторів, яка включила національні й авторські індикатори сталого розвитку. Авторський внесок в оціночну систему визначається загальними індикаторами секторальної ресурсної та екологічної ємності валової доданої вартості, а також структурними індикаторами інвестиційного забезпечення раціонального природокористування в секторі. На основі розроблених методичних положень проведено оцінку стану продовольчої безпеки в аграрному секторі економіки України, експертну та комплексну оцінку позиціювання сектору за його внеском у сталий розвиток держави. Визначено тенденції і проблеми сталого розвитку сировинної ланки агропродовольчого ланцюга вартості, обґрунтовано головні напрями забезпечення продовольчої безпеки в агросфері України.

Ключові слова: аграрний сектор, продовольча безпека, Цілі сталого розвитку, оцінка, секторальні індикатори, валова додана вартість, ресурсна й екологічна ємність.

This work is licensed under a Creative Commons Attribution 4.0 International License http://creativecommons.org/licenses/by/4.0/

Постановка проблеми та її зв'язок з важливими науковими та практичними завданнями. В умовах економічної нестабільності першочерговим завданням держави є забезпечення національної продовольчої безпеки (далі - ПБ), що передбачає проведення моніторингу їі стану на різних рівнях економічної системи та комплексну оцінку індикаторів ПБ, як аналітичне підгрунтя для прийняття збалансованих управлінських рішень. Сьогодні зростає вплив аналітичної інформації на ефективність управлінських рішень державних i регіональних органів влади, суб'єктів господарювання, профільних інституцій на ін. ринкових суб'єктів. Відбувається перегляд і оновлення традиційних підходів до методик оцінки ПБ з урахуванням вимог інституційних трансформацій. Виникають нові аналітичні завдання, такі як моніторинг тенденцій сталого розвитку у секторальному вимірі, оцінка впливу інституційного сектору домогосподарств на сталий розвиток агропродовольчої сфери, оцінка впливу інвестиційних чинників на ресурсну й екологічну ємність окремих секторів економіки тощо.

Відповідно до Указу Президента «Про Цілі сталого розвитку України на період до 2030 р.» від 30 вересня 2019 р. № 722, Цілі сталого розвитку (далі ЦСР) визначено орієнтирами для розроблення проєктів прогнозних і програмних документів, нормативноправових актів $з$ метою забезпечення збалансованості економічного, соціального та екологічного вимірів сталого розвитку України [1]. Відповідно, секторальні індикатори сталого розвитку можуть бути використані для комплексної оцінки національної ПБ, що актуалізує необхідність розробки методичного забезпечення у даній площині.

Аналіз останніх публікацій по проблемі. Діючими методичними рекомендаціями щодо розрахунку рівня економічної безпеки України № 1277 для оцінки ПБ передбачено 11 індикаторів, серед яких

* Публікацію підготовлено в межах НДР «Домінанти інвестиційно-інноваційної політики природокористування національної економіки» за рахунок коштів бюджетної програми «Підтримка розвитку пріоритетних напрямів наукових досліджень» (КПКВК 6541230) 
центральне місце посідає співвідношення обсягів виробництва та споживання продуктів (м'яса та м'ясних продуктів, молока та молочних продуктів, яєць, олії, цукру, картоплі, овочів і баштанних культур, зерна) на одну особу [2]. Слід зазначити, що деякі показники аграрного сектору (зокрема, урожайність основних зернових та зернобобових культур, середній річний удій молока) є індикаторами виробничої безпеки [2], що $є$ свідченням багатовекторного впливу стану агропродовольчого ринку на рівень складових економічної безпеки держави.

Методикою визначення основних індикаторів ПБ [3] передбачено розрахунок 7 індикаторів, а саме: добова енергетична цінність раціону людини, його забезпечення основними видами продуктів, достатність запасів зерна у державних ресурсах, економічна доступність продуктів, диференціація вартості харчування за соціальними групами, ємність внутрішнього ринку окремих продуктів, продовольча незалежність. Лише два індикатора із перелічених є національними індикаторами сталого розвитку у межах ЦСР 1 «Подолання бідності» [4]. Відповідно, виникає необхідність у доповненні методичного забезпечення оцінки ПБ секторальними індикаторами сталого розвитку.

Методичний підхід до комплексної оцінки національної ПБ, що пропонується авторами, полягає в оцінці іiі стану за ланками агропродовольчого ланцюга вартості («сировинна - переробна - збутова споживча ланка - переробка та утилізація відходів») на засадах сталого розвитку. Такий підхід передбачає інтеграцію в систему показників кожної ланки ланцюга певних індикаторів сталого розвитку, що визначає необхідність секторальної дезагрегації національних індикаторів ЦСР. В Україні дане питання розглядається в контексті узгодженості державних секторальних і регіональних політик [5]. Водночас секторальна декомпозиція індикаторів сталого розвитку до- зволить здійснювати горизонтальний аналіз (за секторами) впровадження завдань і ЦСР, визначати внесок кожного сектору в їх реалізацію, що значно розширить систему моніторингу ЦСР в Україні та іiі аналітичний базис. Деякі питання методичного забезпечення оцінки ЦСР в секторальному вимірі в контексті інвестиційно-інноваційної політики раціонального природокористування досліджено в наукових працях Б.В. Буркинського [6], Н.M. Андрєєвої та Г.О. Тютюнник [7]; вплив інституційного сектору домогосподарств (споживча ланка і частково сировинна ланка ланцюга) визначено в праці [8]. Водночас потребує додаткових досліджень питання конструювання системи секторальних індикаторів для оцінки національної ПБ за ланками агропродовольчого ланцюга вартості.

Формулювання цілей дослідження. Мета статті - розробка методичних положень і системи індикаторів для оцінки стану національної продовольчої безпеки на засадах сталого розвитку в аграрному секторі економіки (сировинна ланка ланцюга вартості), проведення експертної і комплексної оцінки впровадження ЦСР в агросфері України.

Виклад основних результатів та їх обгрунтування. У системі Цілей сталого розвитку значною $\epsilon$ роль аграрного сектору у впровадженні завдань ЦСР 2 «Подолання голоду, розвиток сільського господарства», ЦСР 6 «Чиста вода та належні санітарні умови», ЦСР 12 «Відповідальне споживання та виробництво», ЦСР 15 «Захист та відновлення екосистем суші» [4]. Методичні положення до оцінки національної продовольчої безпеки та система економікоекологічних індикаторів сталого розвитку, розроблені авторами, представлені в табл. 1. Використовуючи запропоноване методичне забезпечення, проведемо оцінку ПБ в аграрному секторі України в координатах сталого розвитку.

Таблиця 1

Методичні положення до оцінки національної продовольчої безпеки на засадах сталого розвитку (аграрний сектор) ${ }^{*}$

\begin{tabular}{|c|c|}
\hline Завдання, ЦСР & Індикатори \\
\hline $\begin{array}{l}\text { 1. Достатність інвестиційної } \\
\text { підтримки раціонального при- } \\
\text { родокористування в секторі }\end{array}$ & $\begin{array}{l}\text { 1. Індекс сукупних витрат на охорону НПС (у т.ч. капітальних інвести- } \\
\text { цій та поточних витрат) аграрного сектору, у \% до } 2015 \text { р. } \\
\text { 2. Частка сукупних витрат аграрного сектору у загальних витратах на } \\
\text { охорону НПС в економіці, \% } \\
\text { 3. Частка капітальних інвестицій на охорону НПС у загальних капіта- } \\
\text { льних інвестиціях агросектору, \%" } \\
\text { 4. Частка сукупних витрат на охорону НПС у валовій доданій вартості } \\
\text { аграрного сектору, \%" } \\
\text { 5. Зміни структури капітальних інвестицій на охорону НПС в аграрно- } \\
\text { му секторі за видами природоохоронних заходів, \% }\end{array}$ \\
\hline $\begin{array}{l}\text { 2. Наявність інвестиційної під- } \\
\text { тримки наукових досліджень } \\
\text { та інновацій за напрямом раці- } \\
\text { онального природокористу- } \\
\text { вання в секторі }\end{array}$ & $\begin{array}{l}\text { 6. Частка тематичного напряму «Перспективні технології АПК та пере- } \\
\text { робної промисловості» у бюджетному фінансуванні НДР за напрямом } \\
\text { раціонального природокористування, \%* } \\
\text { 7. Частка тематичного напряму «Проблеми забезпечення продовольчої } \\
\text { безпеки, розширення генофонду с/г сортів рослин і порід тварин» у } \\
\text { бюджетному фінансуванні НДР за напрямом раціонального природо- } \\
\text { користування, \%* }\end{array}$ \\
\hline
\end{tabular}


Продовження табл.1

\begin{tabular}{|l|}
\hline \multicolumn{1}{|c|}{ Завдання, ЦСР } \\
\hline $\begin{array}{l}\text { 3.ЦСР } 15 \text { «Захист та відновлен- } \\
\text { ня екосистем суші» }\end{array}$
\end{tabular}

Завдання 15.3. «Відновити деградовані землі та грунти з використанням інноваційних технологій».

8. Площа орних земель (ріллі), тис. га

9. Частка ріллі у загальній території країни, \%**

10. Частка ріллі у сільськогосподарських угіддях, \% *

11. Площа земель органічного виробництва, тис. га ${ }^{* *}$

12. Частка органічних угідь у сільськогосподарських угіддях, \% **

13. Індекс кількості органічних господарств, у \% до 2015 р. ${ }^{*}$

14. Індекс удобреної площі мінеральними та органічними добривами, у $\%$ до 2015 p."

Покращити якісний стан грунтів $\quad$ 15. Обсяг внесення азотних і фосфорних добрив на 1 га посівної площі, Кг***

4. ЦСР 6 «Чиста вода та належні санітарні умови»

Завдання 6.4. «Підвищити ефективність водокористування». Завдання 6.3 «Зменшити обсяги скидання неочищених стічних вод, насамперед з використанням інноваційних технологій водоочищення на державному та індивідуальному рівнях»;

\section{5. ЦСР 7 «Доступна та чиста енергія»}

Завдання 7.4 «Підвищити енергоефективність економіки»

6. ЦСР 12 «Відповідальне споживання та виробництво»

Завдання 12.1 «Знизити ресурсоємність економіки».

Завдання 12.4

«Зменшити обсяг утворення відходів і збільшити обсяг їх переробки та повторного використанНя»
16. Частка сільського господарства у загальному обсязі забору прісної води секторами економіки, \% *

17. Водоємність ВДВ аграрного сектору, куб.м. забраної прісної води на 1000 грн. ВДВ (у постійних цінах 2016 р.)

18. Індекс водоємності ВДВ аграрного сектору, \% до 2016 p.

19. Частка сільського господарства у загальному обсязі використання прісної води секторами економіки, \% *

20. Частка сільського господарства у загальному обсязі скидів забруднених стічних вод у водні об'єкти України, \% ${ }^{* *}$

21. Частка скидів забруднених стічних вод у водні об'єкти у загальному обсязі скидів за аграрним сектором **

22. Частка сільського господарства у загальному обсязі кінцевого енергоспоживання в Україні, \%*

23. Частка сільського господарства у загальному обсязі використання електроенергії секторами економіки, \%"

24. Частка аграрного сектору у загальному обсязі утворених відходів, $\%$ *

25. Відходоємність ВДВ аграрного сектору, кг на 1000 грн. ВДВ (у постійних цінах 2016 р.) ${ }^{* *}$

26. Індекс відходоємності ВДВ аграрного сектору, \% до 2016 p. *

27. Вуглецевоємність ВДВ сільського господарства, тонни на 1000 грн.

ВДВ (у постійних цінах 2016 р.) **

28. Індекс вуглецевоємності ВДВ сільського господарства, \% до 2016 p. $^{* *}$

29. Вуглецевоємність ВДВ аграрного сектору, тонни на 1000 грн. ВДВ

(у постійних цінах 2016 р.) *

30. Індекс вуглецевоємності ВДВ аграрного сектору, \% до 2016 p.* *

* Індикатор запропоновано авторами;

*** Індикатор за джерелом [4];

**** Індикатор за джерелом [9].

Перші два завдання стосуються інвестиційноінноваційного забезпечення раціонального природокористування в аграрному секторі (див. табл. 1). За статистичними даними, у 2019 р. величина сукупних витрат на охорону навколишнього природного середовища (далі - НПС) в аграрному секторі економіки склала 27,49 млрд. грн., 3 них лише 0,03 \% (5,9 млн. грн.) припадало на капітальні інвестиції, обсяг яких порівняно з 2015 р. зменшився на 73,7 \% (таблиця 2). Натомість динамічно зросли поточні витрати - на $62,5 \%$, які й обумовили зростаючу тенденцію сукупних витрат на охорону НПС в агросфері.
У звітному році частка агросектору у загальних екологічних витратах в економіці України досягла всього 1,01 \%, зменшившись порівняно з 2015 р. на 0,41 в.п. У валовій доданій вартості сектору питома вага його сукупних витрат на охорону природного середовища досягає 7,7 \% та має зростаючий тренд. У структурі загальних капітальних інвестицій сектору частка екоінвестицій у 2019 р. склала всього 0,01\%, зменшившись порівняно з 2015 р. на 0,06 в.п. Мізерні величини структурних індикаторів є свідченням недостатності інвестиційного забезпечення раціонального природокористування в агросфері. 
Динаміка інвестицій на охорону навколишнього природного середовища в аграрному секторі економіки України *

\begin{tabular}{|l|c|c|c|c|c|c|}
\hline \multicolumn{1}{|c|}{ Показники } & \multicolumn{5}{|c|}{ Роки } & $\begin{array}{c}2019 \text { p. } \\
\text { у \% до } \\
2015 \text { p. }\end{array}$ \\
\cline { 2 - 8 } & 2015 & 2016 & 2017 & 2018 & 2019 \\
\hline $\begin{array}{l}\text { 1. Капітальні інвестиції на охорону } \\
\text { НПС, млн. грн. }\end{array}$ & 22,4 & 43,7 & 50,4 & 8,9 & 5,9 & 26,3 \\
\hline $\begin{array}{l}\text { 2. Поточні витрати на охорону НПС в } \\
\text { Україні, млн. грн. }\end{array}$ & 16916 & 19098 & 20466 & 24318 & 27480 & 162,5 \\
\hline $\begin{array}{l}\text { 3. Усього сукупні витрати на охорону } \\
\text { НПС, млн. грн. (1+2) }\end{array}$ & 16938 & 19142 & 20517 & 24327 & 27486 & 162,3 \\
\hline $\begin{array}{l}\text { 4. Частка сукупних витрат аграрного } \\
\text { сектору у загальних витратах на охо- } \\
\text { рону НПС в економіці, \% }\end{array}$ & 1,42 & 1,13 & 1,36 & 1,22 & 1,01 & $\mathrm{X}$ \\
\hline $\begin{array}{l}\text { 5. Частка капітальних інвестицій на } \\
\text { охорону НПС у загальних капітальних } \\
\text { інвестиціях агросектору, \% }\end{array}$ & 0,07 & 0,09 & 0,08 & 0,013 & 0,010 & $\mathrm{X}$ \\
\hline $\begin{array}{l}\text { 6. Частка сукупних витрат на охорону } \\
\text { НПС у доданій вартості аграрного } \\
\text { сектору,\% }\end{array}$ & 7,06 & 6,84 & 6,75 & 6,74 & 7,68 & $\mathrm{X}$ \\
\hline
\end{tabular}

Розраховано авторами за даними Державної служби статистики України $[10,11,12]$

У структурі капітальних інвестицій на охорону природного середовища аграрного сектору в 2019 р. 22,5 \% припадало на очищення зворотних вод, $19 \%$ охорону атмосферного повітря, 54,1 \% - інші заходи (таблиця 3). За 2018-2019 рр. відбулися структурні зміни екоінвестицій в напрямі значного скорочення інвестування заходів поводження 3 відходами (на 37,8 в.п.) та зростання фінансування охорони атмосферного повітря i проблем зміни клімату (на 17,6 в.п.), що відображає зміну пріоритетів інвестиційної політики природокористування в агросфері України.

Таблиця 3

Структура капітальних інвестицій на охорону НПС в аграрному секторі за видами природоохоронних заходів"

\begin{tabular}{|l|c|c|c|c|c|}
\hline \multirow{2}{*}{ Види природоохоронних заходів } & \multicolumn{2}{|c|}{ Обсяги, тис. грн. } & \multicolumn{3}{|c|}{ Структура, \% } \\
\cline { 2 - 6 } & $2018 \mathrm{p}$. & $2019 \mathrm{p}$. & $2018 \mathrm{p}$. & 2019 p. & $\begin{array}{c}\text { Динаміка } \\
\text { 3мін (+,-) }\end{array}$ \\
\hline $\begin{array}{l}\text { 1. Охорона атмосферного повітря і проблеми } \\
\text { зміни клімату }\end{array}$ & 126,3 & 1125 & 1,4 & 19,0 & $+17,6$ \\
\hline 2. Очищення зворотних вод & 2064,8 & 1329,5 & 23,2 & 22,5 & $-0,7$ \\
\hline 3. Поводження з відходами & 3751,8 & 260,3 & 42,2 & 4,4 & $-37,8$ \\
\hline 4. Захист і реабілітація грунту & 50,1 & - & 0,6 & - & $X$ \\
\hline 5. Інші заходи & 2901,2 & 3197,4 & 32,6 & 54,1 & $+21,5$ \\
\hline Всього: & $\mathbf{8 8 9 4 , 2}$ & $\mathbf{5 9 1 2 , 2}$ & $\mathbf{1 0 0 , 0}$ & $\mathbf{1 0 0 , 0}$ & $\mathrm{X}$ \\
\hline
\end{tabular}

* Розраховано авторами за даними Державної служби статистики України $[10,11,12,13]$

Ступінь впровадження завдання щодо інвестиційної підтримки наукових досліджень та інновацій за напрямом раціонального природокористування в аграрному секторі характеризує низка структурних індикаторів (див. табл. 1). Інноваційну складову екоінвестування аграрної сфери характеризують частки відповідних тематичних напрямів у бюджетному фінансуванні НДР та інновацій за пріоритетним напря- мом раціонального природокористування (таблиця 4). У 2020 р. у видовій структурі державного фінансування домінував тематичний напрям «Перспективні технології АПК та переробної промисловості» із часткою 35,3\%, друге місце посів напрям «Технології сталого використання, збереження і збагачення біоресурсів» $(23,9 \%)$. 
Таблиця 4

Динаміка і видова структура бюджетного фінансування НДР та інновацій за пріоритетним напрямом «Раціональне природокористування» в Україні*

\begin{tabular}{|c|c|c|c|c|c|c|c|c|}
\hline \multirow{3}{*}{$\begin{array}{c}\text { Пріоритетний тематичний } \\
\text { напрям }\end{array}$} & \multicolumn{6}{|c|}{ Роки } & \multirow{3}{*}{$\begin{array}{l}2020 \mathrm{p} . \\
\mathrm{y} \% \text { до } \\
2015 \mathrm{p} .\end{array}$} & \multirow{3}{*}{$\begin{array}{c}\text { Зміни } \\
\text { струк- } \\
\text { тури, } \\
\% \\
(6-2) \\
\end{array}$} \\
\hline & \multicolumn{2}{|c|}{2015} & \multirow{2}{*}{2018} & \multirow{2}{*}{2019} & \multicolumn{2}{|c|}{2020} & & \\
\hline & $\begin{array}{l}\text { млн. } \\
\text { грн. }\end{array}$ & $\%$ & & & $\begin{array}{l}\text { млн. } \\
\text { грн. }\end{array}$ & $\%$ & & \\
\hline$A$ & 1 & 2 & 3 & 4 & 5 & 6 & 7 & 8 \\
\hline $\begin{array}{l}\text { 1. Технології сталого використан- } \\
\text { ня, збереження і збагачення біоре- } \\
\text { сурсів, збереження біорізноманіття }\end{array}$ & 42,42 & 18,0 & 79,49 & 79,01 & $\begin{array}{c}104,0 \\
6\end{array}$ & 23,9 & 245,3 & $+5,9$ \\
\hline $\begin{array}{l}\text { 2. Технології моделювання та про- } \\
\text { гнозування стану НПС }\end{array}$ & 31,74 & 13,5 & 39,85 & 41,15 & 56,7 & 13,0 & 178,6 & $-0,4$ \\
\hline $\begin{array}{l}\text { 3.Технології утилізації та видален- } \\
\text { ня ППВ }\end{array}$ & 2,7 & 1,1 & 4,04 & 3,29 & 8,41 & 1,9 & 311,5 & $+0,8$ \\
\hline $\begin{array}{l}\text { 4.Технології підвищення ефектив- } \\
\text { ності очищення стічних вод }\end{array}$ & 4,57 & 1,9 & 17,04 & 18,41 & 27,93 & 6,4 & 611,2 & $+4,5$ \\
\hline $\begin{array}{l}\text { 5.Технології очищення та запобі- } \\
\text { гання забрудненню атмосферного } \\
\text { повітря }\end{array}$ & 0,42 & 0,2 & 4,8 & 2,58 & 3,44 & 0,8 & 819,0 & 0,6 \\
\hline $\begin{array}{l}\text { 6.Технології раціонального вико- } \\
\text { ристання грунтів }\end{array}$ & 27,07 & 11,5 & 45,76 & 42,67 & 41,54 & 9,5 & 153,5 & $-1,9$ \\
\hline $\begin{array}{l}\text { 7.Технології виявлення і оцінки } \\
\text { корисних копалин }\end{array}$ & 28,05 & 11,9 & 32,38 & 24,12 & 32,48 & 7,5 & 115,8 & $-4,4$ \\
\hline $\begin{array}{l}\text { 8.Перспективні технології АПК та } \\
\text { переробної промисловості }\end{array}$ & 98,96 & 41,9 & 121,45 & 91,62 & 153,9 & 35,3 & 155,5 & $-6,6$ \\
\hline $\begin{array}{l}\text { 9. Проблеми забезпечення продо- } \\
\text { вольчої безпеки, розширення ге- } \\
\text { нофонду сільськогосподарських } \\
\text { сортів рослин і порід тварин }\end{array}$ & 0 & 0,0 & 3,76 & 6,64 & 7,34 & 1,7 & $\mathrm{X}$ & $+1,7$ \\
\hline Разом за пріоритетом & 235,93 & 100,0 & 348,57 & 309,49 & 435,8 & 100,0 & 184,7 & $\mathrm{X}$ \\
\hline
\end{tabular}

Розраховано авторами за даними $[14,15]$

Негативною тенденцією є мізерні обсяги фінансування такого важливого напряму, як «Проблеми забезпечення продовольчої безпеки, розширення генофонду сільськогосподарських сортів рослин і порід тварин», значення якого для сталого розвитку агросфери та всієї національної економіки зростає в сучасних умовах нестабільності. У 2020 р. питома вага даного тематичного напряму у структурі фінансування НДР склала всього 1,7 \%, зменшившись порівняно 3 2019 р. на 0,4 в.п. Відтак, наукові дослідження та інновації за напрямом раціонального природокористу- вання в аграрному секторі залишаються інвестиційно незабезпеченими.

Головні індикатори, що характеризують стале використання земельних ресурсів агросфери, узагальнено в таблиці 5. Слід зазначити, що за рівнем забезпеченості сільгоспугіддями (0,87 га/особу) Україна посідає друге місце в Європі (середній індикатор для $Є С$ складає 0,43 га/особу) і є однією із найбільш землезабезпечених країн світу. Водночас продуктивні землі використовуються не достатньо ефективно, вони потерпають від забруднення й ерозії [9, с. 61].

Таблиця 5

Головні індикатори сталого використання земельних ресурсів в Україні*

\begin{tabular}{|c|c|c|c|c|c|c|}
\hline \multirow{2}{*}{ Показники } & \multicolumn{5}{|c|}{ Роки } & \multirow{2}{*}{$\begin{array}{l}\text { 2019p. до } \\
2015 \text { p., \% }\end{array}$} \\
\hline & 2015 & 2016 & 2017 & 2018 & 2019 & \\
\hline 1. Площа сільгоспугідь, тис. га & 41508 & 41505 & 41489 & 41489 & 41311 & 99,5 \\
\hline 2.Площа ріллі, тис. га & 32541 & 32543 & 32544 & 32544 & 32757 & 100,7 \\
\hline y\% до сільгоспугідь & 78,4 & 78,4 & 78,4 & 78,4 & 79,3 & $\mathrm{X}$ \\
\hline у\% до загальної території & 53,9 & 53,9 & 53,9 & 53,9 & 54,3 & $X$ \\
\hline
\end{tabular}


Продовження табл. 5

\begin{tabular}{|c|c|c|c|c|c|c|}
\hline \multirow{2}{*}{ Показники } & \multicolumn{5}{|c|}{ Роки } & \multirow{2}{*}{$\begin{array}{l}2019 \text { p. до } \\
2015 \text { p., \% }\end{array}$} \\
\hline & 2015 & 2016 & 2017 & 2018 & 2019 & \\
\hline 1. Площа сільгоспугідь, тис. га & 41508 & 41505 & 41489 & 41489 & 41311 & 99,5 \\
\hline 3. Площа органічних угідь, тис. га & 410,6 & 411,2 & 420,0 & 429,1 & 468,0 & 114 \\
\hline y\% до сільгоспугідь & 0,99 & 0,99 & 1,01 & 1,03 & 1,13 & $\mathrm{X}$ \\
\hline $\begin{array}{l}\text { 4. Кількість органічних господарств, оди- } \\
\text { ниць }\end{array}$ & 210 & 360 & 375 & 510 & н.д. & в $2,4 \mathrm{p}$. \\
\hline $\begin{array}{l}\text { 5. Удобрена площа, млн. га: } \\
\text { 5.1.мінеральними добривами }\end{array}$ & 14,5 & 15,6 & 16,5 & 16,1 & 16,4 & 113,1 \\
\hline 5.2. органічними добривами & 0,4 & 0,5 & 0,5 & 0,8 & 0,8 & в $2 \mathrm{p}$. \\
\hline $\begin{array}{l}\text { 6.Обсяг внесення азотних і фосфорних до- } \\
\text { брив на } 1 \text { га посівної площі, кг }\end{array}$ & 68 & 83 & 94 & 102 & 102 & 150,0 \\
\hline
\end{tabular}

"Розраховано авторами за даними $[10,12,16]$

У 2019 р. порівняно з 2015 р. площа сільськогосподарських угідь скоротилася на 0,5\%, площа ріллі зросла на 0,7 \% і склала 32,76 млн. га або 79,3 \% від площі сільгоспугідь в Україні (див. табл. 5). Величина площі ріллі перевищила цільове значення індикатора 2025 р. (29760,8 тис. га) на 10,1\%, іiі частка у загальній території країни (54,3 \% в 2019 р.) теж перевищила цільовий орієнтир $(49,3 \%)$ [4, с.109]. В Україні спостерігається стійка тенденція зростання площ органічних угідь. У 2019 р. їх величина склала 468 тис. га, або 1,01 \% від загальної площі сільськогосподарських угідь, майже досягнувши цільового індикатора 2020 р. (500 тис. га); на 2025 р. передбачено його потрійне зростання [4, с.109].

$$
\text { У } 2019 \text { р. в Україні функціонувало }
$$
510 органічних господарств, що вдвічі більше рівня 2015 р. Значна частина органічних господарств сконцентровані в Київській, Одеській, Херсонській, Житомирській, Полтавській, Закарпатській, Львівській областях [16]. Поряд із великими господарствами динамічно зростає кількість малих сертифікованих органічних господарств, створюваних індивідуальними товаровиробниками, зокрема, господарствами на- селення, що доводить вагому роль останніх у сталому розвитку як аграрного сектору, так і всієї економіки. Слід зазначити, що у країнах Свропи більшість органічних господарств $є$ малими, маючи в користуванні декілька гектарів сільгоспугідь. Відтак, освоєння господарствами населення органічної сфери аграрного ринку, з одного боку, відповідає європейській практиці, 3 іншого, дозволяе малим виробникам забезпечити достатню рентабельність для розширеного відтворення ресурсів. Малі органічні господарства спеціалізуються, передусім, на вирощуванні плодоовочевої та ягідної продукції; саме ці ніші займають суб'єкти індивідуального сектору аграрного ринку України [8].

Незважаючи на домінування експорту органічної сировини (зернобобових культур та ягід), вітчизняний органічний ринок поступово зростає за рахунок організації власної переробки органічної сировини. За даними Федерації органічного руху, у 2019 р. обсяг споживчого ринку органічних продуктів в Україні склав 36 млн. євро, збільшившись порівняно 3 2015 р. вдвічі; при цьому приріст органічних площ склав $14 \%$ (рис. 1).

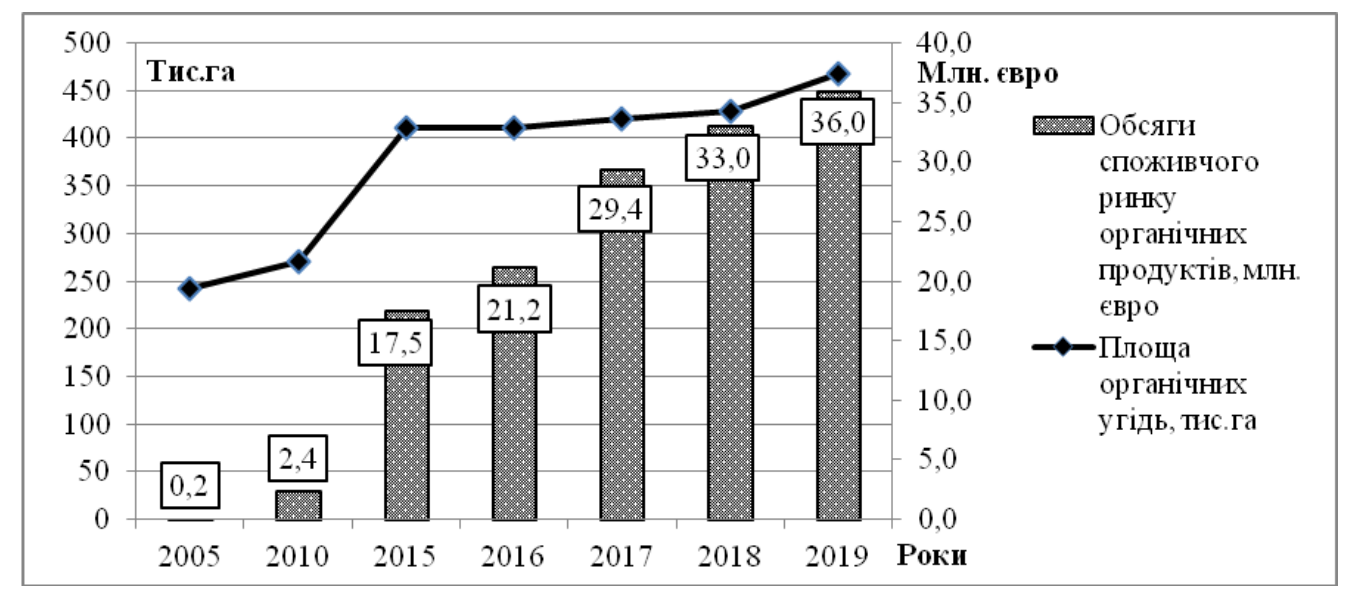

Рис. 1. Динаміка обсягів споживчого ринку органічних продуктів та площ органічних сільськогосподарських угідь в Україні, \%*

*укладено авторами за даними Федерації органічного руху України [16] 
Збереження такої тенденції в майбутньому дозволить забезпечити сталий відтворювальний розвиток вітчизняного органічного ринку та підвищити відтворювальну спроможність домогосподарств, відтак, і їх роль у сталому розвитку агросфери. Слід зазначити, що нарощування обсягів переробки органічної сировини та внутрішнього попиту на органічні продукти є одним із перспективних стратегічних напрямів розвитку агропродовольчого ринку України, орієнтованим на забезпечення національної продовольчої безпеки в умовах нестабільності та збереження НПС.

Водночас тенденція збільшення площ органічних сільгоспугідь не супроводжується достатніми темпами зростання обсягів внесених органічних добрив. У 2010-2017 рр. величина удобреної площі органічними добривами (0,4-0,5 млн. га) залишалася постійною, і лише у 2018-2019 рр. відбулося зростання показника на 0,4 млн. га. За 2015-2019 р. обсяг внесених азотних i фосфорних добрив агровиробниками зріс вдвічі (з 68 до 102 кг /га посівної площі - див. табл. 5). 3 огляду на несприятливий вплив мінералізації сільського господарства на стан навколишнього природного середовища, важливим завданням $є$ дотримання сільгоспвиробниками технологій застосування мінеральних добрив, оптимізації їх величини, нарощування обсягів внесення органічних добрив тощо.

Аграрний сектор є основним споживачем прісної води в Україні, істотно впливаючи на досягнення завдання 6.4 «Підвищити ефективність водокористування» ЦСР 6 «Чиста вода та належні санітарні умови» (див. табл. 1). За 2015-2019 pp. у секторальній структурі забору прісної води в Україні сільське господарство займало перше місце (39,4 \% в 2019 р.), друге й третє місце посідали сектор електроенергетики та житлово-комунального господарства (таблиця 6). За досліджуваний період питома вага аграрного сектору зросла на 6,6 \% за рахунок скорочення часток інших секторів економіки. У 2019 р. сільгосппідприємствами було забрано 4380 млн. куб. м. прісної води, що на 47 \% вище рівня 2015 p.

Секторальна структура забору прісної води в Україні, \%*

Таблиця 6

\begin{tabular}{|l|c|c|c|c|c|c|}
\hline \multirow{2}{*}{ Сектори національної економіки } & \multicolumn{7}{|c|}{ Роки } & $\begin{array}{c}\text { Динаміка } \\
\text { змін } \\
(+,-)\end{array}$ \\
\cline { 2 - 7 } & 2015 & 2016 & 2017 & 2018 & 2019 & $+6,61$ \\
\hline 1. Сільське господарство & 32,81 & 33,84 & 37,01 & 43,89 & $\mathbf{3 9 , 4}$ & $-2,53$ \\
\hline 2. Електроенергетика & 28,27 & 29,15 & 24,61 & 23,94 & 25,7 & $-5,66$ \\
\hline $\begin{array}{l}\text { 3. Житлово-комунальне госпо- } \\
\text { дарство }\end{array}$ & 27,36 & 25,98 & 27,76 & 22,98 & 21,7 & $+1,71$ \\
\hline $\begin{array}{l}\text { 4. Добувна й переробна промис- } \\
\text { ловість, всього, у т.ч.: }\end{array}$ & 9,20 & 8,80 & 8,14 & 6,88 & 10,9 & $+3,01$ \\
\hline $\begin{array}{l}\text { 4.1.Металургійна } \\
\text { 4.2. Хімічна та нафтохімічна }\end{array}$ & 5,02 & 4,70 & 4,49 & 3,90 & 8,0 & $-0,03$ \\
\hline 4.3. Харчова & 0,63 & 0,62 & 0,67 & 0,58 & 0,6 & $-0,12$ \\
\hline 5. Інші сектори & 2,76 & 2,58 & 2,90 & 2,65 & 2,73 & $-0,03$ \\
\hline
\end{tabular}

"Розраховано авторами за даними Державної служби статистики України $[10,11,12]$

Для діагностики водоємності секторів економіки авторами запропоновано розрахунок індикатора секторальної водоємності валової доданої вартості (ВДВ) у постійних цінах 2016 р., який дозволить здійснити порівняльний аналіз ефективності водоко- ристування різних секторів, визначити найбільш водоємні серед них. Базуючись на даних Державної служби статистики України, авторами розраховано індикатор водоємності ВДВ у секторальному вимірі (таблиця 7).

Таблиця 7

Секторальна водоємність валової доданої вартості (ВДВ), куб. м. забраної прісної води на тис. грн. ВДВ у постійних цінах 2016 р. *

\begin{tabular}{|c|c|c|c|c|c|}
\hline \multirow{2}{*}{ Сектори } & \multicolumn{4}{|c|}{ Роки } & \multirow{2}{*}{$\begin{array}{c}2019 \mathrm{p} . \\
\mathrm{y} \% \text { до } 2016 \mathrm{p} .\end{array}$} \\
\hline & 2016 & 2017 & 2018 & 2019 & \\
\hline 1.Усі сектори економіки & 3,91 & 3,53 & 4,24 & 4,26 & 108,9 \\
\hline 2.Сільське господарство & 11,28 & 11,70 & 15,92 & 14,69 & 130,2 \\
\hline 3. Електроенергетика & 36,82 & 30,89 & 36,17 & 41,88 & 113,7 \\
\hline $\begin{array}{l}\text { 4. Добувна та переробна промис- } \\
\text { ловість }\end{array}$ & 1,94 & 1,64 & 1,69 & 2,78 & 143,2 \\
\hline
\end{tabular}

"Розраховано авторами за даними Державної служби статистики України $[10,11,12]$ 
В Україні за рівнем водоємності валової доданої вартості аграрний сектор займає друге місце в економіці після електроенергетики. У 2019 р. індикатор водоємності ВДВ в агросфері склав 14,69 куб. м. на 1000 грн. ВДВ у постійних цінах 2016 р, перевищивши середнє значення індикатора для всіх секторів економіки в 3,4 рази. Порівняно з 2016 р. величина водоємності ВДВ агросектору зросла на $30,2 \%$, що пов'язано з вищими темпами приросту обсягів забору прісної води (39\%) порівняно з ВДВ сільського господарства (рис. 2).

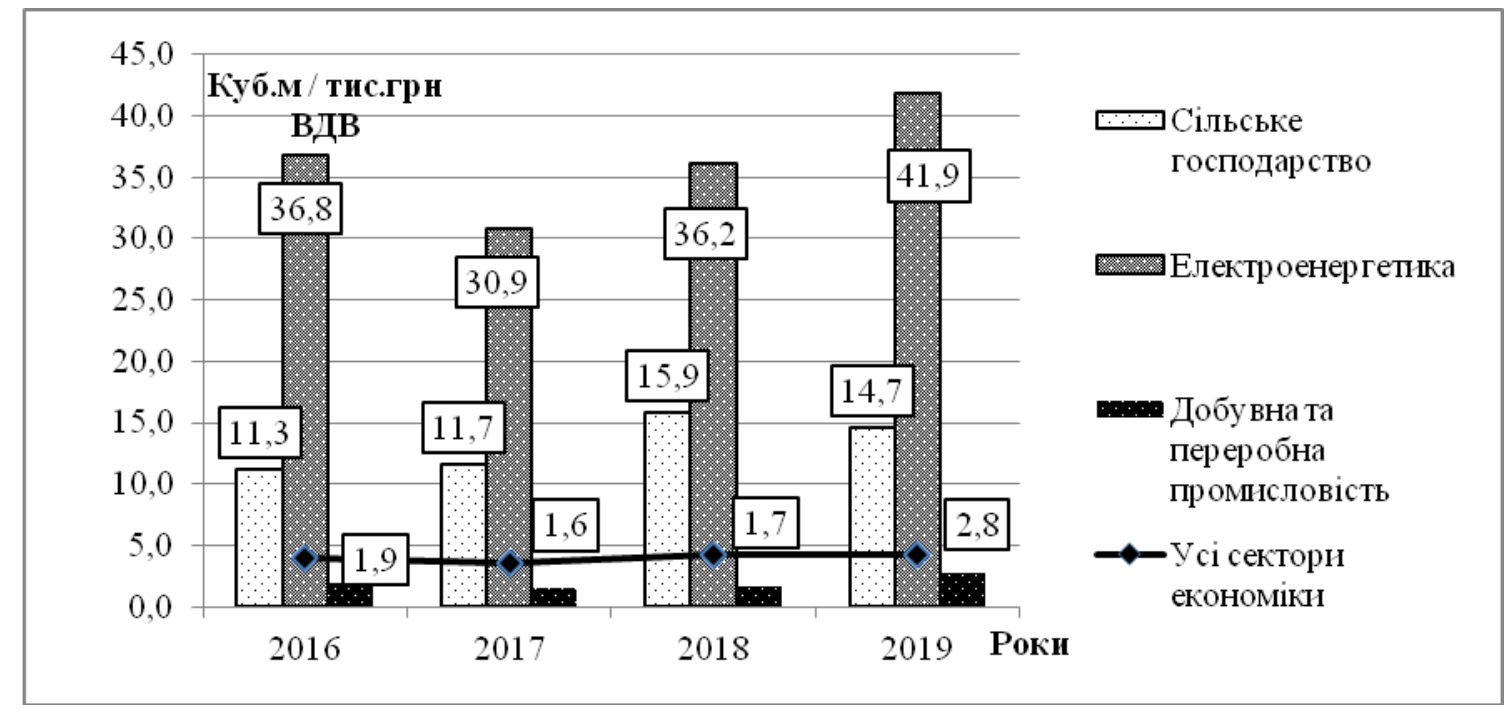

Рис. 2. Динаміка індикатора водоємності ВДВ у постійних цінах 2016 р. у секторальному вимірі, куб. м на 1000 грн. ВДВ

у укладено авторами за даними табл. 7.

У 2019 р. питома вага аграрного сектору в загальному обсязі використання прісної води склала 26,3 \% (1793 млн. куб. м), посівши друге місце після енергетики в секторальній структурі. У звітному році частка зрошення у структурі використання прісної води досягла 19,7 \%, що вище рівня 2015 р., але нижче величини 2018 р. (рис. 3). Частка сільськогосподарського водопостачання $є$ незначною і варіює в межах 0,4-0,6\%.
У секторальній структурі скидів забруднених стічних питома вага сільського господарства в 2019 р. досягла 6,3\%, що вдвічі вище рівня 2015 р. У звітному році частка скидів забруднених стічних вод у водні об'єкти у загальному обсязі скидів аграрного сектору зросла порівняно з 2018 р. майже втричі і склала $12,4 \%$, перевищивши цільове значення індикатора 2025 р. в $10 \%$, що $є$ свідченням невиконання сектором завдання 6.3 ЦСР 6 [4].

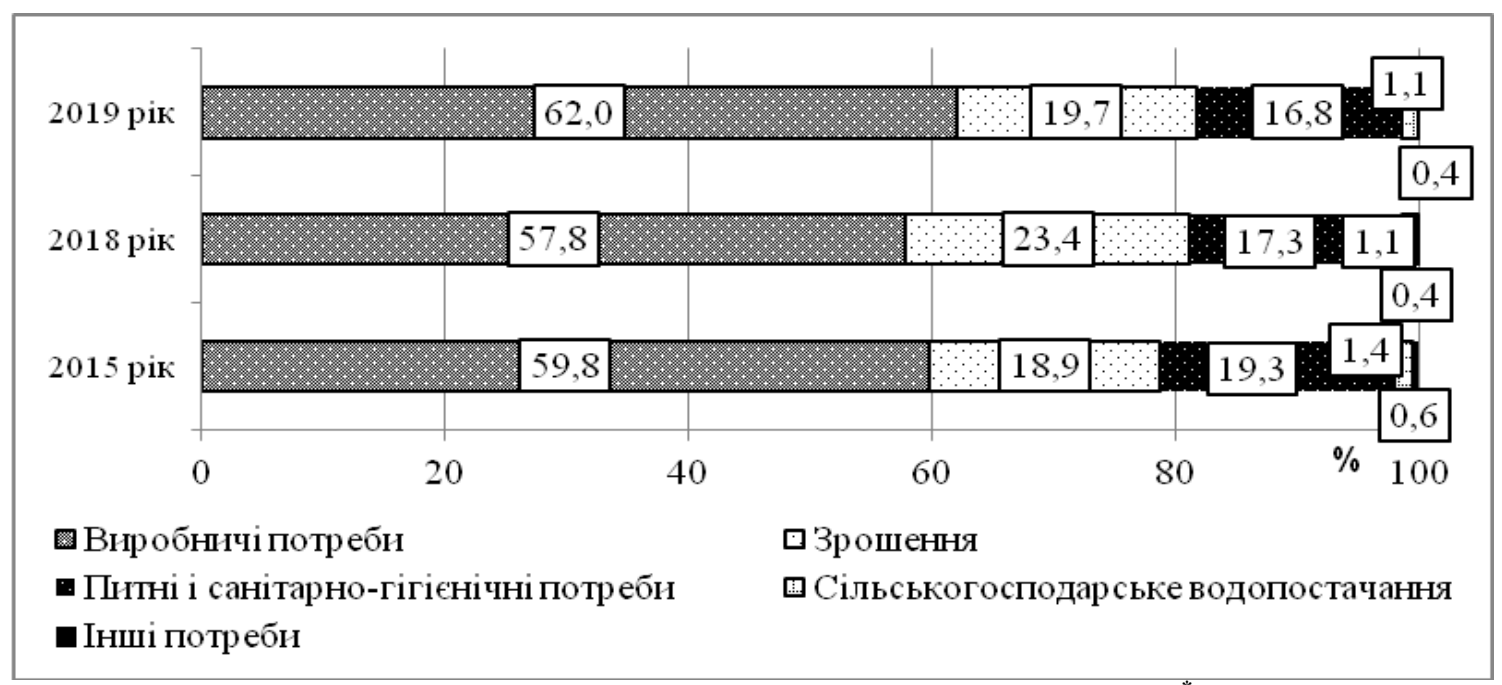

Рис. 3. Структура використання прісної води в Україні, \% " укладено авторами за даними Державної служби статистики України $[10,11,12]$

Серед секторів національної економіки сільське господарство є найменшим споживачем енергії (рис. 4). В структурі кінцевого енергоспоживання за 2015-2019 р. частка аграрного сектору була відносно стабільною і складала 3,7-3,9\%. У 2019 р. сільське господарство спожило 1890 тис. т н.е. енергії, що на 3,6\% менше рівня 2015 р. [10]. 


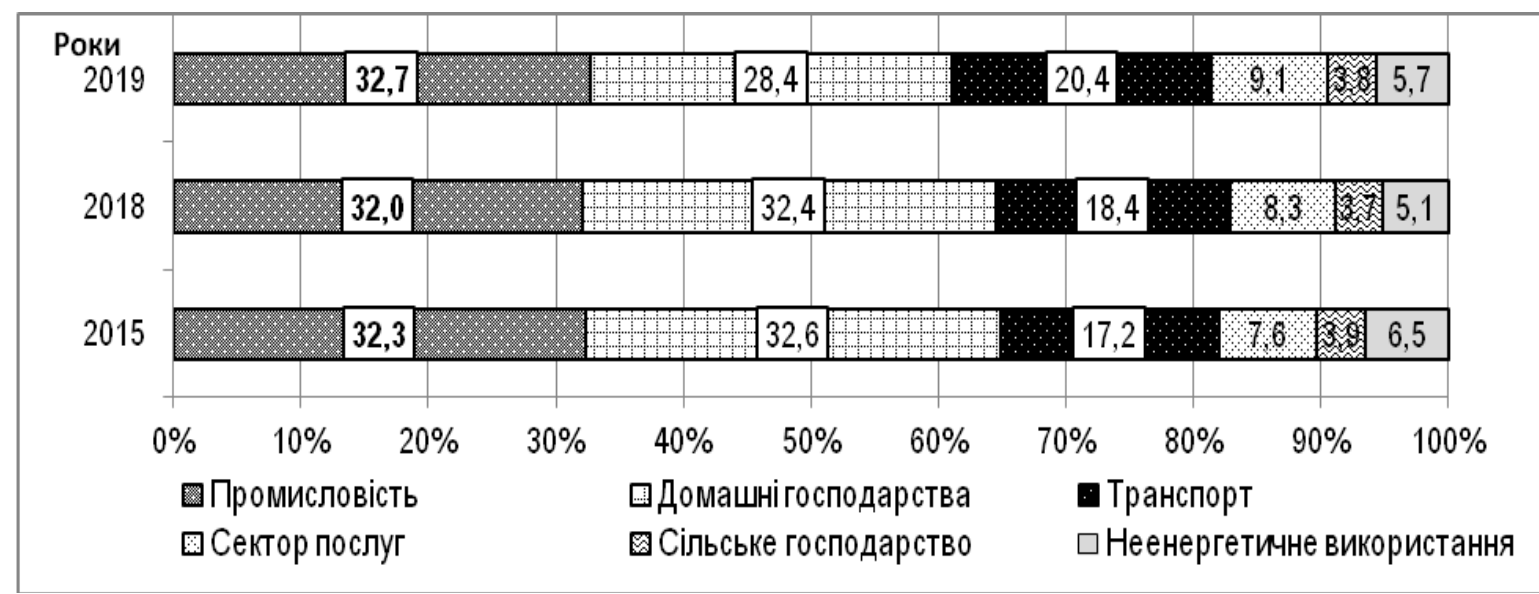

Рис. 4. Секторальна структура кінцевого енергоспоживання в Україні, \%

*побудовано за даними Державної служби статистики України [10]

У загальному обсязі використання електроенергії секторами економіки питома вага аграрного сектору є однією з найменших і складає в 2019 р. 2,71 \%, що на 0,65 в.П. менше рівня 2015 р. У звітному році суб'єкти аграрного сектору спожили 2405,3 млн. кВтгод. електроенергії, що на 5,4\% менше величини 2015 p. [10].
У 2019 р. обсяг утворених відходів в агросфері склав 6,75 млн. т або 1,5 \% від їх загального обсягу в країні (рис. 5). Рівень відходоємності ВДВ в сільському господарстві $(22,65$ кг / тис. грн.) в 7,5 p. нижчий середнього індикатора (169,24 кг / тис. грн.) i $\epsilon$ найнижчим серед секторів національної економіки [17].

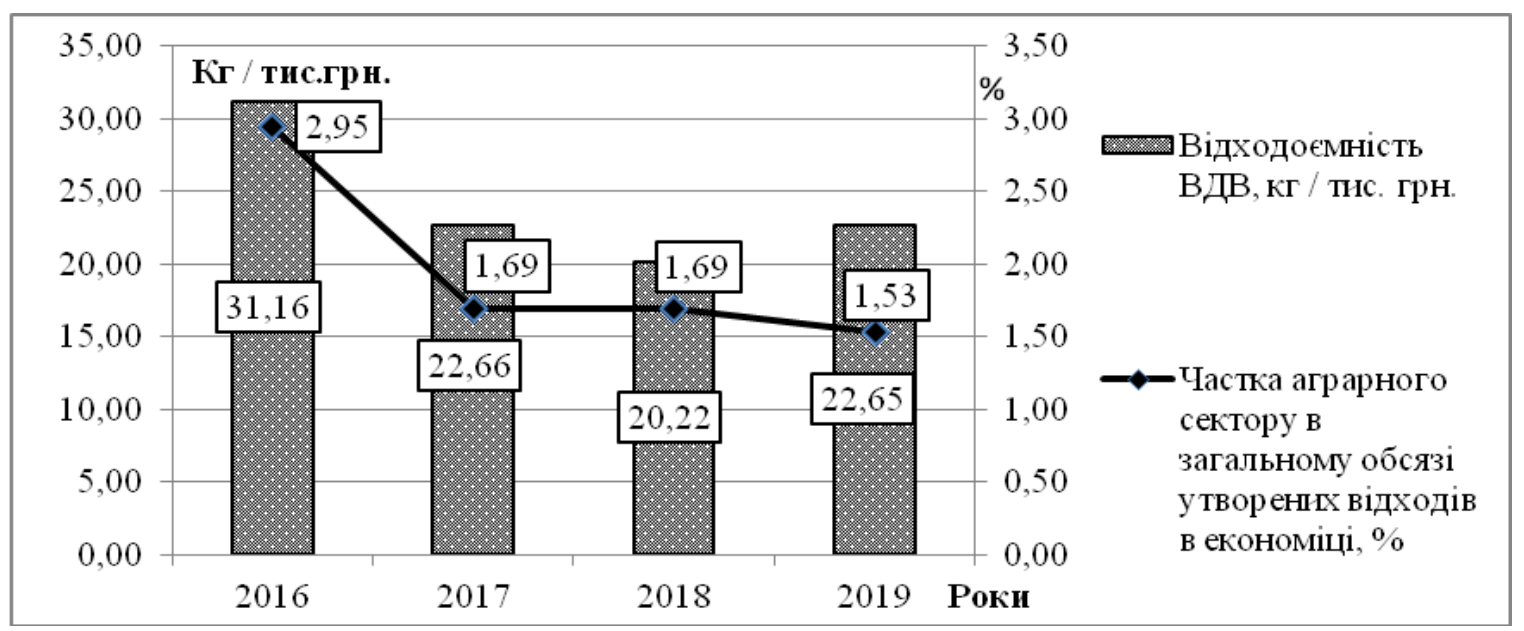

Рис. 5. Динаміка відходоємності ВДВ аграрного сектора, кг/тис. грн. ВДВ у порівняних цінах 2016 р.* укладено авторами за даними Державної служби статистики України $[10,11,12]$

За 2016-2019 рр. наявна позитивна тенденція скорочення обсягів утворених відходів в агросекторі (на $23 \%$ ) та рівня іiї відходоємності (на $27 \%$ ). Це є свідченням впровадження пріоритету зниження екодеструктивного впливу агросфери на стан НПС та досягнення цільових орієнтирів сталого розвитку.

Динаміка індикатора вуглецевоємності ВДВ секторів національної економіки представлена в таблиці 8. У 2019 р. в цілому по економіці індикатор досягнув 46,49 т / тис. грн. (у постійних цінах 2016 р.), зменшившись порівняно з 2015 р. на 26,4 \%. Рівень вуглецевоємності ВДВ переробного сектору в 3,4 рази вищий середнього рівня по економіці і складає 156,42 т / грн., займаючи друге місце після енергетичного сектору. Найменше значення індикатора притаманне сільському господарству - 3,9 т / тис. грн. та добувній промисловості - 24,95 т / тис. грн.; ці сектори за 2016-2019 рр. мали зростаючу динаміку показника (приріст склав 24,1 \% і 10,3 \% відповідно). Серед секторів національної економіки скорочувальний тренд вуглецевоємності ВДВ мають переробна промисловість та енергетичний сектор. Індикатори інших секторів за 2016-2019 рр. мають незначний зростаючий тренд.

Для визначення ступеню впливу аграрного сектору на реалізацію завдань і Цілей сталого розвитку держави використаємо метод експертних оцінок. Шкала оцінки ступеню реалізації ЦСР в секторах економіки включає чотири типи бальних оцінок: (1) низький - 0-2 бали; (2) середній - 3-5 бали; (3) достатній - 6-8 балів; (4) високий - 9-10 балів [7, c. 67]. 
Таблиця 8

Динаміка секторальної вуглецевоємності валової доданої вартості (ВДВ) у постійних цінах 2016 р. в Україні, т / тис. грн.*

\begin{tabular}{|c|c|c|c|c|c|}
\hline \multirow{2}{*}{ Сектори економіки } & \multicolumn{4}{|c|}{ Роки } & \multirow{2}{*}{$\begin{array}{l}2019 \text { p. у \% } \\
\text { до } 2016 \text { p. }\end{array}$} \\
\hline & 2016 & 2017 & 2018 & 2019 & \\
\hline 1. Всього по економіці & 63,13 & $\mathbf{5 0 , 8 2}$ & $\mathbf{5 0 , 0 0}$ & 46,49 & 73,6 \\
\hline 2.Сільське господарство & 3,14 & 4,03 & 3,98 & 3,90 & 124,1 \\
\hline $\begin{array}{l}\text { 3.Добувна промисловість і розроблення } \\
\text { кар'єрів }\end{array}$ & 22,62 & 27,21 & 30,71 & 24,95 & 110,3 \\
\hline 4.Переробна промисловість & 209,57 & 160,57 & 154,91 & 156,42 & 74,6 \\
\hline $\begin{array}{l}\text { 5.Постачання електроенергї̈, газу, пари } \\
\text { та кондиційованого повітря }\end{array}$ & 1071,37 & 928,30 & 966,15 & 926,63 & 86,5 \\
\hline $\begin{array}{l}\text { 6. Водопостачання; каналізація, пово- } \\
\text { дження } 3 \text { відходами }\end{array}$ & 28,01 & 31,57 & 18,23 & 30,14 & 107,6 \\
\hline
\end{tabular}

*Розраховано авторами за даними Державної служби статистики України $[10,11,12]$

Результати проведеної оцінки національної ПБ в аграрному секторі формують достатне аналітичне підгрунтя для проведення експертного опитування фахівців 3 питань природокористування та сталого розвитку національної економіки.

Слід зазначити, що експертна оцінка здійснювалася тільки за загальними індикаторами сталого розвитку, що розраховуються для всіх секторів економіки, з метою проведення на наступному етапі міжсекторального аналізу та здійснення позиціювання секторів у досягненні ЦСР в Україні.
Результати експертної оцінки впровадження завдань і Цілей сталого розвитку (див. табл. 1) в розрізі загальних індикаторів сталого розвитку представлено в таблицях 9 i 10. Для аграрного сектору притаманний високий рівень реалізації завдання 4 «Зниження екодеструктивного впливу сектору на стан НПС» і достатній рівень впровадження завдання 3 «Стале використання складових природно-ресурсного потенціалу»; за напрямом інвестиційного та інноваційного забезпечення раціонального природокористування (завдання 1 і 2) агросфера отримала середню та низку бальні оцінки (див. табл. 9).

Таблиця 9

Результати експертної оцінки впровадження завдань 1 і 2 «Достатнє інвестиційно-інноваційне забезпечення раціонального природокористування» в аграрному секторі ${ }^{*}$

\begin{tabular}{|c|c|c|c|c|c|c|c|}
\hline \multicolumn{4}{|c|}{$\begin{array}{c}\text { Завдання 1: Достатність інвестиційної підтримки } \\
\text { раціонального природокористування }\end{array}$} & \multicolumn{4}{|c|}{$\begin{array}{c}\text { Завдання 2: Наявність інвестиційної підтримки } \\
\text { наукових досліджень та інновацій за напрямом } \\
\text { раціонального природокористування }\end{array}$} \\
\hline $\begin{array}{l}\text { Загальні } \\
\text { індикатори }\end{array}$ & 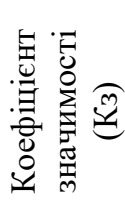 & 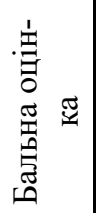 & 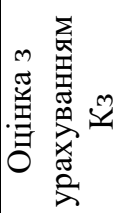 & $\begin{array}{l}\text { Загальні } \\
\text { індикатори }\end{array}$ & $\hat{1}$ & 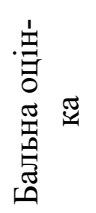 & 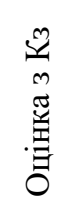 \\
\hline $\begin{array}{l}\text { 1.Частка сукупних витрат } \\
\text { сектору у загальних витра- } \\
\text { тах на охорону НПС в еко- } \\
\text { номіці, \% }\end{array}$ & 0,35 & 1 & 0,35 & $\begin{array}{l}\text { 1.Частка реалізованої іннова- } \\
\text { ційної продукції в загальному } \\
\text { обсязі, \% }\end{array}$ & 0,65 & 0 & 0 \\
\hline $\begin{array}{l}\text { 2.Частка капітальних інвес- } \\
\text { тицій на охорону НПС у } \\
\text { загальних капітальних інве- } \\
\text { стиціях сектору, \% }\end{array}$ & 0,35 & 1 & 0,35 & \multirow{2}{*}{$\begin{array}{l}\text { 2.Частка тематичного напря- } \\
\text { му у бюджетному фінансу- } \\
\text { ванні НДР за напрямом раці- } \\
\text { онального природокористу- } \\
\text { вання, \% }\end{array}$} & \multirow[t]{2}{*}{0,35} & \multirow[t]{2}{*}{5} & \multirow[t]{2}{*}{1,75} \\
\hline $\begin{array}{l}\text { 3.Частка сукупних витрат на } \\
\text { охорону НПС у ВДВ секто- } \\
\text { ру, \% }\end{array}$ & $\mathbf{0 , 3 0}$ & 8 & 2,40 & & & & \\
\hline Всього: & 1,00 & $X$ & 3,10 & Всього: & 1,00 & $\mathrm{X}$ & $\overline{1,75}$ \\
\hline
\end{tabular}

*Узагальнені результати експертного опитування 
Результати експертної оцінки впровадження завдань 3 і 4 «Стале використання природно-ресурсного потенціалу» в аграрному секторі*

\begin{tabular}{|c|c|c|c|c|c|c|c|}
\hline \multicolumn{4}{|c|}{$\begin{array}{c}\text { Завдання 3: Стале використання складових } \\
\text { природно-ресурсного потенціалу }\end{array}$} & \multicolumn{4}{|c|}{$\begin{array}{c}\text { Завдання 4: Зниження екодеструктивного } \\
\text { впливу сектору на стан НПС }\end{array}$} \\
\hline $\begin{array}{l}\text { Загальні } \\
\text { індикатори }\end{array}$ & 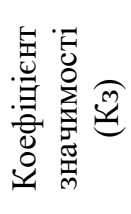 & 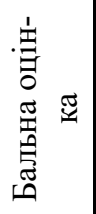 & 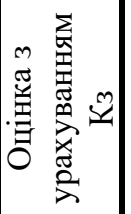 & $\begin{array}{l}\text { Загальні } \\
\text { індикатори }\end{array}$ & $\tilde{s}$ & 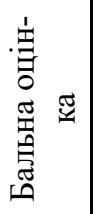 & 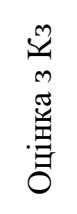 \\
\hline $\begin{array}{l}\text { 1. Водоємність ВДВ секто- } \\
\text { ру, куб.м. забраної прісної } \\
\text { води на } 1000 \text { грн. ВДВ (у } \\
\text { постійних цінах } 2016 \text { р.) }\end{array}$ & $\mathbf{0 , 3 0}$ & 7,50 & 2,25 & $\begin{array}{l}\text { 1.Відходоємність ВДВ секто- } \\
\text { ру, кг на } 1000 \text { грн. ВДВ (у } \\
\text { постійних цінах } 2016 \text { р.) }\end{array}$ & 0,20 & $\begin{array}{c}10,0 \\
0\end{array}$ & 2,00 \\
\hline $\begin{array}{l}\text { 2.Індекс водоємності ВДВ } \\
\text { сектору, \% до } 2016 \text { р. }\end{array}$ & 0,40 & 6,00 & 2,40 & $\begin{array}{l}\text { 2.Індекс відходоємності ВДВ } \\
\text { сектору, \% до } 2016 \text { р. }\end{array}$ & $\mathbf{0 , 3 0}$ & $\begin{array}{c}10,0 \\
0\end{array}$ & 3,00 \\
\hline \multirow{2}{*}{$\begin{array}{l}\text { 3. Частка сектору у загаль- } \\
\text { ному обсязі використання } \\
\text { електроенергії секторами } \\
\text { економіки, \% }\end{array}$} & \multirow[t]{2}{*}{$\mathbf{0 , 3 0}$} & \multirow[t]{2}{*}{9,50} & \multirow[t]{2}{*}{2,85} & $\begin{array}{l}\text { 3. Вуглецевоємність ВДВ сек- } \\
\text { тору, тонни на } 1000 \text { грн. ВДВ } \\
\text { (у постійних цінах } 2016 \text { р.) }\end{array}$ & 0,20 & $\begin{array}{c}10,0 \\
0\end{array}$ & 2,00 \\
\hline & & & & $\begin{array}{l}\text { 4. Індекс вуглецевоємності } \\
\text { ВДВ сектору, \% до } 2016 \text { р. }\end{array}$ & $\mathbf{0 , 3 0}$ & 3,00 & 0,90 \\
\hline Всього: & 1,00 & $\mathrm{X}$ & 7,50 & Всього: & 1,00 & $X$ & 7,90 \\
\hline
\end{tabular}

*Узагальнені результати експертного опитування

Місце і роль аграрного сектору в сталому розвитку держави дозволяє визначити комплексна оцінка позиціювання секторів національної економіки за їх внеском у сталий розвиток (таблиця 11). За їі результатами, серед секторів економіки агросфера має найнижчий рівень реалізації завдань щодо інвестиційноінноваційного забезпечення природокористування та найвищий рівень впровадження завдань щодо сталого використання природно-ресурсного потенціалу i зниження екодеструктивного впливу на стан природного середовища. Загалом серед секторів економіки переважає середній і достатній рівень реалізації завдань (див. табл. 11), що свідчить про їх нереалізований потенціал сталого розвитку.

Таблиця 11

Комплексна оцінка позиціювання секторів національної економіки за їх внеском у сталий розвиток України*

\begin{tabular}{|c|c|c|c|c|c|}
\hline \multirow[b]{2}{*}{ Завдання } & \multicolumn{5}{|c|}{ Сектори економіки } \\
\hline & Аграрний & Добувний & Переробний & $\begin{array}{l}\text { Енерго- } \\
\text { постачання }\end{array}$ & $\begin{array}{l}\text { Водо- } \\
\text { постачання }\end{array}$ \\
\hline $\begin{array}{l}\text { 1. Достатнє інвестиційне забезпе- } \\
\text { чення раціонального природокори- } \\
\text { стування }\end{array}$ & $\begin{array}{c}3,1 \\
\text { середній }\end{array}$ & $\begin{array}{c}5,7 \\
\text { достатній }\end{array}$ & $\begin{array}{c}5,8 \\
\text { достатній }\end{array}$ & $\begin{array}{c}8,35 \\
\text { високий }\end{array}$ & $\begin{array}{c}9,65 \\
\text { високий }\end{array}$ \\
\hline $\begin{array}{l}\text { 2. Інвестиційне забезпечення НДР } \\
\text { та інновацій за напрямом сталого } \\
\text { розвитку }\end{array}$ & $\begin{array}{c}1,75 \\
\text { низький }\end{array}$ & $\begin{array}{c}1,70 \\
\text { низький }\end{array}$ & $\begin{array}{c}3,70 \\
\text { середній }\end{array}$ & $\begin{array}{c}0,35 \\
\text { низький }\end{array}$ & $\begin{array}{c}1,05 \\
\text { низький }\end{array}$ \\
\hline $\begin{array}{l}\text { 3. Стале використання складових } \\
\text { природно-ресурсного потенціалу }\end{array}$ & $\begin{array}{c}\text { 7,5 } \\
\text { достатній }\end{array}$ & $\begin{array}{c}5,7 \\
\text { достатній }\end{array}$ & $\begin{array}{c}5,4 \\
\text { середній }\end{array}$ & $\begin{array}{c}5,4 \\
\text { середній }\end{array}$ & $\begin{array}{c}7,45 \\
\text { достатній }\end{array}$ \\
\hline $\begin{array}{l}\text { 4. Зниження екодеструктивного } \\
\text { вПливу секторів на стан НПС }\end{array}$ & $\begin{array}{c}7,9 \\
\text { високий }\end{array}$ & $\begin{array}{c}3,1 \\
\text { середній }\end{array}$ & $\begin{array}{c}7,7 \\
\text { достатній }\end{array}$ & $\begin{array}{c}6,7 \\
\text { достатній }\end{array}$ & $\begin{array}{c}6,1 \\
\text { достатній }\end{array}$ \\
\hline
\end{tabular}

*Складено авторами за даними [6, с.83 ]

Висновки та перспективи подальших досліджень. Запропоновано авторський методичний підхід до комплексної оцінки національної продовольчої безпеки за ланками агропродовольчого ланцюга вар- тості на засадах сталого розвитку. Розроблено методичні положення та систему індикаторів (загальних і специфічних) сталого розвитку аграрного сектору, яка комплементарно поєднала 6 національних 
індикаторів ЦСР, 23 авторських індикатора і один показник «зеленого» зростання (див. табл. 1). Авторський внесок у дану систему визначається загальними індикаторами секторальної ресурсної та екологічної ємності валової доданої вартості (водоємності, відходоємності та вуглецевоємності ВДВ). Для оцінки інвестиційного забезпечення раціонального природокористування в секторі запропоновано три загальні індикатори, серед яких: частка капітальних інвестицій на охорону НПС у загальних капітальних інвестиціях сектору, частка сукупних витрат на охорону НПС у валовій доданій вартості сектору. До специфічних індикаторів сталого розвитку аграрного сектору належить група показників оцінки ЦСР 15 «Захист та відновлення екосистем суші». Використовуючи розроблене методичне забезпечення, здійснено оцінку стану ПБ в аграрному секторі України (сировинна ланка ланцюга вартості) за 2015-2019 pp.

За результатами проведеної оцінки встановлено найнижчий серед секторів економіки рівень реалізації завдань щодо інвестиційно-інноваційного забезпечення раціонального природокористування в агросфері. Так, частка капітальних інвестицій на охорону НПС у загальних капітальних інвестиціях аграрного сектору складає всього $0,01 \%$. Водночас тематичний напрям «Перспективні технології АПК та переробної промисловості» займає вагому частку в бюджетному фінансуванні НДР за напрямом раціонального природокористування (35,3 \% у 2020 р.). Аграрний сектор є одним із найбільш водоємних секторів національної економіки, займаючи у секторальній структурі забору прісної води в 2015-2019 рр. перше місце (39\% в 2019 р.). За індикатором водоємності ВДВ (14,7 куб. м. на 1000 грн. ВДВ у постійних цінах 2016 р.), що має зростаючий тренд, аграрний сектор посів друге місце (після електроенергетики), перевищивши значення загального індикатора в 3,4 рази. Серед секторів економіки сільське господарство $\epsilon$ найменшим споживачем енергії $(3,8 \%$ в кінцевому енергоспоживанні) та найменш відходо- та вуглецевоємним сектором; рівні індикаторів відходоємності
ВДВ (22,7 кг / тис. грн.) та вуглецевоємності ВДВ (3,9 т / тис. грн.) в агросфері значно нижчі інших секторів. Головними напрямами забезпечення національної продовольчої безпеки на засадах сталого розвитку є зростання державних видатків на НДР та інновації за пріоритетним тематичним напрямом «Проблеми забезпечення продовольчої безпеки, розширення генофонду сільськогосподарських сортів рослин і порід тварин», стимулювання сільськогосподарських товаровиробників до впровадження ресурсозберігаючих технологій, створення сприятливого інституційного середовища для виробництва і переробки органічної сировини, стимулювання об'єднання господарств населення в органічні кооперативи і покращення їх доступу до органічного сегменту ринку, надання пільгових кредитів і податкових преференцій суб'єктам, що впроваджують екоінновації в агросфеpi, створення розвиненої інфраструктури із переробки відходів, розвиток міжсекторального партнерства, збалансування обмежувальних і компенсаційних методів і заходів регулювання на основі європейських практик.

Наукова новизна проведеного дослідження полягає у вдосконаленні методичного базису для комплексної оцінки національної продовольчої безпеки у координатах сталого розвитку, розробці та апробації нових секторальних індикаторів, що дозволяють визначити місце і роль аграрного сектору в реалізації завдань ЦСР в Україні. Прикладна значимість розроблених методичних положень визначається можливістю їх використання органами влади різних рівнів, профільними інституціями та іншими стейкхолдерами в ході горизонтального аналізу (за секторами) впровадження ЦСР, здійснення горизонтальної та вертикальної координації секторальних політик, розробки адаптивних механізмів раціонального природокористування в агросекторі. Перспективи подальших досліджень полягають у розширенні методичного базису за рахунок нових індикаторів оцінки продовольчої безпеки в переробній та збутовій ланках агропродовольчого ланцюга вартості.

\section{Література}

1. Про Цілі сталого розвитку України на період до 2030 року: Указ Президента України від 30 вересня 2019 p. № 722/2019. URL: https://zakon.rada.gov.ua/laws/show/722/2019. (дата звернення: 5.10.2021)

2. Методичні рекомендації щодо розрахунку рівня економічної безпеки України: Затверджено Наказом Міністрества економічного розвитку і торгівлі України № 1277 від 29.10.2013 p. URL: https://zakon.rada.gov.ua/rada/show/v1277731-13\#Text (дата звернення: 5.10.2021)

3. Деякі питання продовольчої безпеки: Постанова Кабінету Міністрів України №1379 від 05.12.2007 р. Ред. від 21.10.2011, підстава 1041-2011-п. URL: https://zakon.rada.gov.ua/laws/show/1379-2007\% 0\%BF\#Техt(дата звернення: 5.10.2021)

4. Цілі Сталого Розвитку: Україна: Національна доповідь 2017. Міністерство економічного розвитку і торгівлі України, 2017. 176 с.

5. Державна стратегія регіонального розвитку на 2021-2027 роки: затверджена Постановою Кабінету Міністрів України №695 від 05 серпня 2020 p. URL: https://zakon.rada.gov.ua/laws/show/695-2020$\%$ D0\%BF\#Tехt(дата звернення: 5.10.2021)

6. Буркинський Б.В., Нікішина О.В., Чеботарьова Н.Й. Методичні положення щодо діагностики домінант інвестиційно-інноваційної політики природокористування в секторальному вимірі: наук. доповідь. Одеса: ІПРЕЕД НАН України, 2021. 108 с. 
7. Андрєєва Н.М., Тютюнник Г.О. Методичні підходи щодо визначення домінант регіональної інвестиційно-інноваційної політики природокористування: наукова доповідь. Одеса: ІПРЕЕД НАН України, 2020. $101 \mathrm{c}$.

8. Нікішина О.В. Діагностика впливу інституційного сектору домогосподарств на сталий розвиток економіки України. Food Industry Economics. 2021. 13(3). C.3-15. URL: https://journals.onaft.edu.ua/index.php/fie/article/view/2127/2313. doi: 10.15673/fie.v13i3.2127 (дата звернення: 5.10.2021)

9. Доповідь про зелену трансформацію в Україні на основі показників «зеленого» зростання ОЕСР. Міністерство економічного розвитку і торгівлі України, 2016. 60 с.

10. Офіційний сайт Державної служби статистики України. URL: http://www.ukrstat.gov.ua/ (дата звернення: 7.10.2021)

11. Довкілля України за 2018 рік: статистичний збірник. За ред. О. М. Прокопенко. Київ: Державна служба статистики України, 2019. 214 с.

12. Довкілля України за 2019 рік: статистичний збірник. За ред. О. М. Прокопенко. Київ: Державна служба статистики України, 2019. 214 с.

13. Капітальні інвестиції на охорону навколишнього природного середовища за видами економічної діяльності з розподілом за видами природоохоронних заходів у 2018, 2019 році. URL: http://www.ukrstat.gov.ua/ (дата звернення: 7.10.2021)

14. Реалізація пріоритетних напрямів розвитку науки і техніки та отримані результати в 2020 році: аналітична довідка. К.:УкрIHTEI, 2021. 58 c. URL: https://mon.gov.ua/ua/nauka/nauka/informacijno-analitichnimateriali (дата звернення: 7.10.2021)

15. Реалізація пріоритетних напрямів розвитку науки і техніки та отримані результати в 2019 році: аналітична довідка. К.:УкрIHTEI, 2020. 60 c. URL: https://mon.gov.ua/ua/nauka/nauka/informacijno-analitichnimateriali (дата звернення: 7.10.2021)

16. Офіційний сайт Федерації органічного руху в Україні: Органік в Україні. URL: http://organic.com.ua/organic-v-ukraini/ (дата звернення: 7.10.2021)

17. Нікішина О.В. Діагностика екологічної ємності національної економіки у секторальному вимірі.

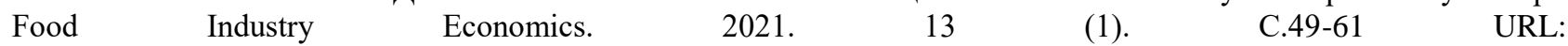
https://journals.onaft.edu.ua/index.php/fie/article/view/1988/2186. doi: 10.15673/fie.v13i1.1988 (дата звернення: 7.10.2021)

Стаття надійшла 20.10.2021

Стаття прийнята до друку 3.11.2021 Доступно в мережі Internet 30.12.2021

\author{
Nikishyna 0 . \\ Doctor of Economics, Senior Researcher \\ Head of Department of Market Mechanisms and Structures \\ E-mail: ksenkych@gmail.com \\ ORCID ID: 0000-0002-7172-3551 \\ Chebotarova N. \\ Postgraduate \\ Department of Market Mechanisms and Structures \\ Institute of Market Problems and Economic \& Ecological Research \\ of National Academy of Sciences of Ukraine \\ Frantsuzskiy boulevard, 29, Odesa, Ukraine, 65044 \\ E-mail: chebotarovan@ukr.net \\ ORCID ID: 0000-0003-1790-5925
}

\title{
METHODICAL PROVISIONS FOR THE ASSESSMENT OF NATIONAL FOOD SECURITY ON THE BASIS OF SUSTAINABLE DEVELOPMENT
}

The article proposes a methodical approach to a comprehensive assessment of national food security by links of the agri-food value chain on the basis of sustainable development. Methodical provisions for the assessment of food security in the agricultural sector (raw material link of the value chain) and a system of general and specific indicators have been developed, which has included national and author's indicators of sustainable development. The author's contribution to the evaluation system is determined by the general indicators of the sectoral resource and environmental capacity of gross value added, as well as structural indicators of investment support for the rational use of nature in the sector. 
On the basis of the developed methodical provisions the estimation of a condition of food safety in agrarian sector of economy of Ukraine has been carried out, tendencies and problems of its sustainable development have been defined. The low level of realization of tasks concerning investment and innovation maintenance of rational nature use in agrosphere has been established. Thus, the share of capital investments in environmental protection in the total capital investments of the sector is only $0.01 \%$. The agricultural sector is one of the most water-intensive sectors of the national economy, according to the indicator of water intensity of gross value added, it ranks second. Among the sectors of the economy, agriculture is the smallest energy consumer and the least waste- and carbon-intensive sector.

An expert and comprehensive assessment of the positioning of the agricultural sector according to its contribution to the sustainable development of the state has been carried out. It has been established that among the sectors of the economy the agro-sphere has the highest level of implementation of tasks on sustainable use of natural resource potential and reduction of eco-destructive impact on the state of the environment.

The main directions of food security in the agricultural sector of Ukraine have been substantiated, in particular: growth of state expenditures on innovations in the priority thematic area "Problems of food security», incentives for agricultural producers to introduce resource-saving technologies and organic production, incentives to unite farms into organic cooperatives, development of infrastructure for waste processing, balancing of restrictive and compensatory methods and regulatory measures based on European practices.

Key words: agricultural sector, food security, Sustainable Development Goals, evaluation, sectoral indicators, gross value added, resource and ecological capacity.

\section{References}

1. Pro Tsili staloho rozvytku Ukrainy na period do 2030 roku: Ukaz Prezydenta Ukrainy vid 30 veresnia 2019 r. № 722/2019. zakon.rada.gov.ua. (2019). Retrieved October 5, 2021, from https://zakon.rada.gov.ua/laws/show/722/2019

2. Metodychni rekomendatsii shchodo rozrakhunku rivnia ekonomichnoi bezpeky Ukrainy: Zatverdzheno Nakazom Ministrestva ekonomichnoho rozvytku i torhivli Ukrainy № 1277 vid 29.10.2013 r. zakon.rada.gov.ua. (2013). Retrieved October 5, 2021, from https://zakon.rada.gov.ua/rada/show/v1277731-13\#Text

3. Deiaki pytannia prodovolchoi bezpeky: Postanova Kabinetu Ministriv Ukrainy №1379 vid 05.12.2007 r. Red. vid 21.10.2011, pidstava 1041-2011-p. zakon.rada.gov.ua. (2011). Retrieved October 5, 2021, from https://zakon.rada.gov.ua/laws/show/1379-2007-\%D0\%BF\#Text

4. Ministerstvo ekonomichnoho rozvytku i torhivli Ukrainy. (2017). (rep.). Tsili Staloho Rozvytku (pp. 1176).

5. Derzhavna stratehiia rehionalnoho rozvytku na 2021-2027 roky: zatverdzhena Postanovoiu Kabinetu Ministriv Ukrainy №695 vid 05 serpnia 2020 r. zakon.rada.gov.ua. (2020). Retrieved October 5, 2021, from https://zakon.rada.gov.ua/laws/show/695-2020-\%D0\%BF\#Text

6. Burkynskyi, B. V., Nikishyna, O. V., \& Chebotarova, N. Y. (2021). (rep.). Metodychni polozhennia shchodo diahnostyky dominant investytsiino-innovatsiinoi polityky pryrodokorystuvannia $v$ sektoralnomu vymiri (pp. 1-108). Odesa: IPREED NAN Ukrainy.

7. Andrieieva, N. M., \& Tiutiunnyk, H. O. (2020). (rep.). Metodychni pidkhody shchodo vyznachennia dominant rehionalnoi investytsiino-innovatsiinoi polityky pryrodokorystuvannia (pp. 1-101). Odesa: IPREED NAN Ukrainy.

8. Nikishyna, O. V. (2021). Diahnostyka vplyvu instytutsiinoho sektoru domohospodarstv na stalyi rozvytok ekonomiky Ukrainy. Food Industry Economics, 13(3), 3-15. Retrieved October 5, 2021, from https://journals.onaft.edu.ua/index.php/fie/article/view/2127/2313. doi: 10.15673/fie.v13i3.2127

9. Ministerstvo ekonomichnoho rozvytku i torhivli Ukrainy. (2016). (rep.). Dopovid pro zelenu transformatsiiu v Ukraini na osnovi pokaznykiv «zelenoho» zrostannia OESR (pp. 1-60).

10. Ofitsiinyi sait Derzhavnoi sluzhby statystyky Ukrainy. Retrieved October 7, 2021, from http://www.ukrstat.gov.ua/

11. Prokopenko, O. M. (Ed.). (2019). Dovkillia Ukrainy za 2018 rik. Derzhavna sluzhba statystyky Ukrainy.

12. Prokopenko, O. M. (Ed.). (2019). Dovkillia Ukrainy za 2019 rik. Derzhavna sluzhba statystyky Ukrainy.

13. Kapitalni investytsii na okhoronu navkolyshnoho pryrodnoho seredovyshcha za vydamy ekonomichnoi diialnosti z rozpodilom za vydamy pryrodookhoronnykh zakhodiv u 2018, 2019 rotsi. ukrstat.gov.ua. Retrieved October 7, 2021, from http://www.ukrstat.gov.ua/

14. UkrINTEI. (2021). Realizatsiia priorytetnykh napriamiv rozvytku nauky i tekhniky ta otrymani rezultaty $v$ 2020 rotsi: analitychna dovidka. Retrieved October 7, 2021, from https://mon.gov.ua/ua/nauka/nauka/informacijnoanalitichni-materiali.

15. UkrINTEI. (2020). Realizatsiia priorytetnykh napriamiv rozvytku nauky i tekhniky ta otrymani rezultaty $v$ 2019 rotsi: analitychna dovidka. Retrieved October 7, 2021, from https://mon.gov.ua/ua/nauka/nauka/informacijnoanalitichni-materiali 
16. Orhanik v Ukraini. Retrieved October 7, 2021, from http://organic.com.ua/organic-v-ukraini/

17. Nikishyna, O. V. (2021). Diahnostyka ekolohichnoi yemnosti natsionalnoi ekonomiky u sektoralnomu vymiri. Food Industry Economics, 13(1), 49-61. Retrieved October 7, 2021, from https://journals.onaft.edu.ua/index.php/fie/article/view/1988/2186. doi: 10.15673/fie.v13i1.1988

Received 20 October 2021

Approved 3 November 2021

Available in Internet 30.12.2021

Цитування згідно ДСТУ 8302:2015

Нікішина О.В., Чеботарьова Н.Й. Методичні положення щодо оцінки національної продовольчої безпеки на засадах сталого розвитку // Економіка харчової промисловості. 2021. Т. 13, вип. 4. С. 48-62. doi 10.15673/fie.v13i4.2192

Cite as APA style citation

Nikishyna, O. \& Chebotarova, N. (2021). Methodical provisions for the assessment of national food security on the basis of sustainable development. Food Industry Economics, 13(4), 48-62. doi 10.15673/fie.v13i4.2192 